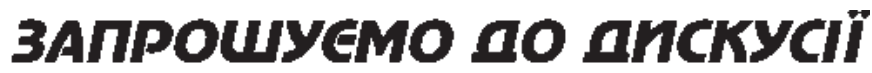

УДК 910.1:930.1(100) «1950/2000»

https://doi.org/10.15407/ugz2017.01.066

\section{Б.О. Чернов}

Переяслав-Хмельницький державний педагогічний університет імені Григорія Сковороди

\section{ЄДНІСТЬ ГЕОГРАФІЇ: МІФ ЧИ РЕАЛЬНІСТЬ?}

\begin{abstract}
Світова криза 60-х - початку 90-х років минулого століття охопила і географрічну науку, що спричинило загальну світову тенденцію посилення диференціації галузевих географічних дисциплін, але на цьому фоні зріс інтерес і до інтеграції, до комплексної фрізичної та суспільної географрії й необхідності обґрунтування єдиної географрії. У статті викладено історіографрічний огляд намагань зарубіжних географів другої половини XX століття довести єдність географії на фоні поширених нині абстрактних математичних моделей або ігнорування єдності взагалі. Висловлюється й думка про неможливість в найближчий час об'єднання двох гілок географії.
\end{abstract}

Ключові слова: фрізична географрія; соціально-економічна географрія; суспільна географрія; єдність географії; проблеми єдності; варіанти єдності; ігнорування єдності географрії.

\section{B.O. Chernov}

Hryhoryi Skovoroda Pereiaslav-Khmelnytskyi State Pedagogical University

\section{THE UNITY OF GEOGRAPHY: MYTH OR REALITY?}

The world crisis of the 60 -s the beginning of the 90 -s years of the past century covered the geographical science, which caused a general world tendency as strengthening sectoral differentiation of geographic subjects, but all this increased interest to integration, and to complex physical and social geography and the need to substantiate the unified geography. A historiographic analysis showed an attempt of foreign geographers to prove the unity of geography from excogitated unsubstantiated suggestions to abstract mathematical models or neglect of unity in general. It has been suggested to impossibility union of the two branches of geography in the near future.

Keywords: physical geography; socio-economic geography; social geography; unity geography; the problem of unity; variants of unity; neglect unity geography.

\section{Актуальність дослідження}

Питання єдності й суті географічної науки виникло майже одразу після їі роз'єднання у X1X ст., але серйозно його почали обговорювати з розвитком науково-технічної революції. В Росії, закінчуючи аналіз існуючої концепції «розірваної» географії у період ії кризи 1960-1970-х рр., В. О. Анучин зазначав, що «становлення географії виявилось процесом більш тривалим, ніж це уявлялося. На наш погляд, воно тільки ще підходить до свого завершення (на 1972 р. - Б. Ч.), після чого почнеться новий етап в історії нашої науки - етап прискореного розвитку» [1, с. 129]).

Але через 14 років А.Г. Ісаченко зробив ретельний огляд наукових праць російських учених, у яких 3 різною повнотою й обгрунтуванням йшлося про можливість єдності фізичної та суспільної географії в Росії, і дійшов висновку: «Проблема інтеграції географічних наук не виникла б, якби був у цих наук загальний предмет дослідження» [4, с. 377].

Підштовхнула географів до пошуку шляхів інтеграції також праця В. Бунге (W. Bunge) «Теоретична географія», в якій він неоднозначно доводив можливість єдності географії на основі математичних методів дослідження. Застосування в теорії математики дозволило побачити багато раніше невідомих законів земних просторів, охарактеризувати явища в їх складних зв'язках, в новому світлі і, спираючись на теорію, дати прогноз на майбутнє. Суть математизації географії полягає у тому, що вона дозволяє швидше і успішніше відкривати і застосовувати об'єктивні закони науки. Проте не маючи глибоких теоретикометодологічних географічних знань, почали моделювати природні об'єкти і структури. Це призвело до тих наслідків, про які І. Г. Ісаченко писав, що в «теоретичній географії» усе різноманіття об'єктів, які досліджують географічні науки, постає в якомусь стерилізованому вигляді; змістовний бік об'єктів розглядається як «різні нашарування, які слід відкинути. Географія з науки про реальності перетворюється на науку про деякі абстрактні моделі реальності» [4, с. 383].

Одразу виникають питання: чи можливе об'єднання географії взагалі? Якщо можливе, то як будуть об'єднуватись об'єкти дослідження 3 різними законами i закономірностями розвитку? Пропозицій багато, але всі вони на рівні побажань. Незважаючи на критику «теоретичної географії» і відмову від іiі абстрактних побудов, ще й нині вітчизняні географи (див. «Український географічний журнал» № 2, 2016) 
висловлюють пропозиції загальним об’єктом географії вважати «не матеріальні субстанції, не системи речей, а відношення та системи відношень», тобто «модель-уявлення».

Досліджуючи це питання, важливо простежити підходи учених різних географічних шкіл західних країн.

Мета цього дослідження - аналіз розвитку географічної думки зарубіжних географів у 60-х - початку 90-х pр. ХХ століття про єдність географії.

\section{Виклад основного матеріалу}

Аналіз літературних джерел показує, що зарубіжні вчені - географи намагалися відгукнутися на нові глобальні виклики, які постали перед ними на початку другої половини XX ст., зрозуміти причини поділу географії на дві галузі знань і знайти підходи до об'єднання. Оскільки уявлення російських учених про розв'язання проблеми ретельно вивчене й висвітлене [4 та ін.], тому увагу зосереджено на аналізі праць західних учених.

Короткий екскурс в історію означеної проблеми зроблено за працею професора університету Кларка (США) Анни Баттімер (Anna Battimer) «Шлях у географію» [2].

Уперше програму з географії було прийнято в Норвегії в університеті Осло у 1871 р. Через десять років (1881) Географічна асоціація Фінляндії географію зарахувала до природничих наук, вона мала стійке положення популярної науки, але у 1910 р. між науковцями виникла суперечка про природу географії. Голова Географічного товариства Фінляндії Сьодерхольм (Soderholm) відстоював думку про те, що географія не є самостійною наукою, а є сумою різних дисциплін. Вчені Русберг (Rusberg) та Ю. Гране (Yu. Granö), захищаючи інтереси своєї науки, стверджували, що географія незалежна і єдина.

У цей час (1887 р.) єдина географія в Нідерландах зазнала поділу на природну і соціальну гілки, а у 1912 р. фізична і соціальна географія набули законного права на існування двох різних університетських програм.

Розмежування географії на фізичну і соціально-економічну відбулося на самому початку XX ст. і у Франції. Підтвердженням існування двох гілок географії було опублікування підручників: 3 фізичної географії Е. де Мартонна (Е. de Martonne; 1909) та соціально-економічної Дж. Брюнеса (J. Brunhes; 1910). Відаль де ла Блаш (Vidal de la Blache; 1913, 1922) кардинальним принципом вважав єдність географії та створив для неї як теоретичну основу, так і певні структурні гарантії. У теоретичному відношенні єдність географії як науки повинна відображати ідею єдності ії земного об'єкта. За таким широким поглядом можуть намічатися різні програми досліджень: оцінка індивідуальності окремих країн або регіонів, а також пошук спільності й навіть причин формування існуючого обличчя земної поверхні.

Натомість у США на початку XX ст. фізична географія продовжувала залишатись основним полем досліджень. Тут уперше у 1919 р. Феннеман (Fenneman) довів, що регіональні дослідження є об'єднуючим ядром географії. Незважаючи на це, у 1920 р. відбувся поділ географії на фізичну і соціально-економічну, закріплений новими програмами в університетах.

Подібна ситуація відбулась і у Швеції. У 1930-ті рр. Г. Нельсон (H. Nelson) намагався перебороти розкол, що розпочався між фізичною і соціально-економічною географією, але на початку 1940-х pp. і 3 кафедри географії були створені окремі кафедри фізичної та соціально-економічної географії.

Після виходу у Франції монографії «Тропічні країни» П'єра Гуру (Pier Guru) було рішуче заявлено, що саме регіональна географія сприяє єдності фізичної та соціально-економічної географії, причому клімат вважається головним об’єднуючим чинником у поясненні як природних, так і соціальних явищ.

Натомість, у Великій Британії співіснування фізичної і соціально-економічної географії було порушене підвищеним інтересом до проблем навколишнього середовища i ресурсокористування, які почали розглядатися як засоби об’єднання фізичної та соціально-економічної географії [2].

Суперечливий процес дослідження єдності географії активізувався у період кризи географії у 19601970-ті pp. ${ }^{1}$

Так, німецький географ Ернст Вінклер (Ernst Winkler) пише, що «виходячи з єдності науки як безперервного процесу пізнання навколишнього світу, географії притаманні спеціальний об' єкт дослідження і методологічна основа. Проте, виходячи 3 концепції єдиної географії, неможливо дати повний

\footnotetext{
${ }^{1}$ При огляді цього і наступних періодів до раніше названого джерела [2] долучено аналіз анотацій у реферативному журналі (РЖ) «География: А. Теоретические и общие вопросы географии». Москва. У посиланнях вказано: РЖ, рік, номер та сторінки.
} 
аналіз ландшафту тільки з позиції галузей. Саме ландшафт потребує діагностичного, прогностичного, терапевтичного і профілактичного дослідження. Тільки з позиції єдиної географії, оволодівши географічними знаннями, людина зможе активно впливати на умови свого буття». [О научности географии (пер. с нем.). РЖ. 1969. № 2 А9. С. 2.].

Але англійський дослідник К. Георге (Kish George) вважає по-іншому - фізичну та економічну географію може об'єднати тільки політична географія, за допомогою якої можна усунути численні політичні конфлікти, передбачити численні протиріччя, хоча додає, що синтезуючу роль відіграє географія населення. К. Георге вважає, що оскільки початковий смисл грецького терміну «географія» втратив своє значення, то «географія нині має глибоко «людський» зміст. Це вже не опис Землі, а характеристика людини на Землі. Тому найбільша головна мета географії - пояснення причин розподілу населення на Землі. Це визначає взаємозв'язок явищ, цементує усі розділи географії та є керівництвом для розвитку географії як цілісної науки». [Разделы географии и её единство (пер. с англ.). РЖ. 1969. № 2 А11. С. 3.].

Г. Уліг (H. Uhlig) і Е. Ятес (Е. Yates) вважають, що без одночасного вивчення природних і соціальних чинників неможливо дати наукове пояснення особливостям регіональних географічних систем. На їх думку, однобічність двох основних напрямків географії може бути подолана на базі об'єднаної ландшафтної географіï, яка має вивчати взаємодію компонентів геокомплексів. [Организация географии и система географических наук (пер. с англ.). РЖ. 1972. № 3 А4. С. 2.].

\section{Але при иъьоу немає пояснення самої «об’єднаної ландщафтної географії»².}

У той же час Рональд Кооке (Ronald Cooke) вважає, що методологічною базою об'єднання фізичної географії з соціальною є застосовування системного підходу і системного синтезу, яке може бути досягнуто під час дослідження взаємовідношень між структурними частинами систем. [Системы и физическая география (пер. с англ.). РЖ. 1972. № 4 А40. С. 5.].

Зауважимо, що в такому контексті невідомо, на яких саме структурних частинах будуть «досліджуватися взаємовідночення».

Серед зарубіжних географів найгрунтовніше навів докази можливого об'єднання географії Дж. Гюнтер (John M. Hunter). Він представив складну структуру географії з іiї поділом на систематичну та регіональну. Регіональна географія має своїм завданням вивчення розподілу явищ по поверхні Землі за трьома можливими підходами: 1 - вивчення усіх явищ в обмеженому районі; 2 - вивчення одного явища у всесвітньому масштабі; 3 - вивчення окремих явищ в обмеженому районі.

Систематична географія, за цим автором, поділяється на фізичну і географію людини. Загальним для систематичної та регіональної гілок географії $\epsilon$ часовий аспект вивчення об'єктів. Географію об’єднують також загальні географічні концепції та загальні методи. Серед перших розрізняються: 1 - уявлення про простір, розподіл явищ у просторі, просторові взаємодії; 2 - уявлення про цілісність географічного середовища, загальний взаємозв'язок фізичних, біологічних і соціальних компонентів; 3 - концепції про взаємовідношення людини і середовища: посибілізм, географічний детермінізм та інші. Серед загальногеографічних методів (груп методів) виділено такі: картографічний, аерофотографічний, кількісні. Доповнюють об’єднання географії концепції й моделі теоретичної географії, аналіз систем тощо. [Структура географии. Пояснения к предварительной модели (пер. с англ.). РЖ. 1972. № 4 А4. С. 1.]

Докази об'єднання географії, наведені Дж. Гюнтером, майже збігаються з аналогічними доказами російських учених і сприяють подальшому розвитку методологічних засад об'єднання географії 3 урахуванням «часового аспекту», «загальних географічних концепцій і загальних методів дослідження».

Протилежною є думка деяких американських учених, наприклад, Джулії Туасон (Julie Tuason A.), які, аналізуючи єдність інтеграції й диференціації географічної науки, роблять висновок, що спроби учених віднести географію до системи природничих чи суспільних наук $\epsilon$ штучними, тому географію потрібно розглядати як прикладну міждисциплінарну науку [9].

Зауважимо: при иьвому дві потужні гілки справжньої науки раптом перетворюються на прикладні штучні науки, як і вся географічна наука.

\footnotetext{
${ }^{2}$ Світлим курсивом виділено коментарі автора статті
} 
Натомість португальські географи, наприклад Пентеадо Ореллана (Penteado Orellana), Маргаріда М. (Margarida M.) розглядають методологічні проблеми географії як єдиної науки, без поділу на фізичну географію та географію людини і без поділу фізичної географії на окремі галузеві дисципліни. [Сферы физико-географических исследований (пер. с порт.). РЖ. 1988. № 6 А28. С. 4-5.].

Англійський географ К. Дж. Джонстон (К. J. Jonston) у першому виданні (1979) праці «Географія і географи: нарис розвитку англо-американської соціальної географії після 1945 року» висловив переконання у тому, що «сьогоднішні зв'язки соціогеографії та фізичної географії слабкі, і використання подібних методів та підходів недостатньо для їх об’єднання в одну науку», а у другому виданні (1987) вже стверджував, що «точок дотику між цими науками стає дедалі менше, хоча їх предмети стикаються, обидві вони мають більше зв'язків з іншими дисциплінами, ніж одна з одною» [5, с. 536].

Інший англійський географ К. Грегорі (K. Gregory) в праці «Географія і географи: фізична географія» (1988) навіть не торкається питання взаємовідносин і шляхів інтеграції в географії. Він тільки зауважує, що це нерозв'язана проблема і що, на думку деяких авторів, «фізична і соціально-економічна географія дедалі більше віддаляються одна від одної... і через невідповідність теоретичних завдань соціально-економічної та фізичної географії важко позбутися відцентрових тенденцій».

Уже сам факт розмежування між двома авторами сфери географії на два блоки - фізичний і соціальноекономічний - характерний для західної науки. Причому, обидві праці відтворюють погляди представників англо-американської географії [5, с. 538].

Цікавою є й думка американських географів П. Джеймса (P. Dzheims) і Дж. Мартіна (D. Martin), які в праці «Усі можливі світи: історія географічних ідей» (1988) тільки наприкінці констатують «еклектичну і моральну плутанину сьогоднішньої (американської) географії та роблять песимістичний висновок, що єдність географії залишається ілюзорною» [5, с. 540].

Підводячи підсумки 20-річного розвитку англо-американської географії (до 1990 р. - Б. Ч.), Е. Граган (E. Grahan) відмічає, що географія пройшла шлях від стану методологічної наївності до періоду методологічного розброду. Кількісна революція на початку 60-х рр. відкрила перед одними географами нові можливості для дослідження, в той час як для інших обіцяний значний теоретичний і науковий прогрес так і не реалізувався.

Короткий період післяреволюційної ейфорії завершився у 1969 р., і в наступні роки «нові географії» тільки боролися за самоутвердження. Внаслідок цього відбулася безпрецедентна i, напевно, все ще посилена фрагментація спільноти дослідників-географів англо-американської географії, їх інституційне роз'єднання, а також епістемологічне роз'єднання, яке виражається в тому, що різні географи сповідують різні наукові ідеології та йдуть різними шляхами до розв'язання досліджуваних завдань. Тому актуальною практичною метою стає подолання кризи самосвідомості в географії з метою набуття ширшого погляду на дійсність, яка вивчається. [Единство в англо-американской географии (пер. с англ.). РЖ. 1990. № 3 А21. C. 4.].

Португальські географи Мюллер Фільхо (Müller Filho) та Іво Лауро (Ivo Lauro) вважають, що це, напевно, пов'язане із загостренням протиріч між систематичною і регіональною географією і дедалі більшим віддаленням фізичної й суспільної географії. Поширюється думка, що регіоналізм у географії визначає іiі цілісність і є найяскравішим прикладом застосування географічного методу. Разом з тим, зростає й число прибічників єдності фізичної, суспільної і біологічної географії. [К пониманию классических подходов в географии (пер. с порт.). РЖ. 1990. № 3 А85. С. 12.].

Натомість французький географ Георге Перре (George Pierre) вважає предметом географії глобальне вивчення середовища життя, яке по-різному використовують різні людські колективи впродовж історії, та спротив, що проявляє простір у різних точках руху, який слід розуміти і як розвиток. [Трудности и сомнения географии (пер. с франц.). РЖ. 1976. № 10 А8. С. 2-3.]. Крім того, він вважає, що перешкодою для синтетичного підходу є диференціація географічної науки, особливо схематизм, у дослідженнях (багато елементів географічної ситуації не можуть бути формалізовані). Учений також підкреслює, що вимірювання елементів, які зазнають формалізації, часто пов'язане з величезними витратами, які можливі тільки з утилітарною метою [там само].

Словенський географ I. Гамз (I. Gams) переконаний, що нині у центрі географічних досліджень $є$ вплив людини на визначеній території, тоді як у науках про середовище об' єктом вивчення є вплив середовища на людину. «Отже, - зазначає вчений, - за цих умов практично здійснилося розділення географії на фізичну, яка вивчає регіональну структуру, і економічну, яка висвітлює соціально-економічні процеси. Розрив між цими дисциплінами поглиблюється і стає загрозливим для подальшого розвитку географії». [Среда - среда 
человека - географическая среда - география (пер. со словен.). - РЖ. - 1978. - № 6 А7. - С. 2.].

Цікавими $є$ міркування польського вченого С. Березовські (S. Berezovski) про проблеми інтеграції та дезінтеграції географічної науки в історичному плані. Він вважає, що у X1X ст. панували ідеї детермінізму, основна ідея якого полягала в абсолютизації впливу географічного середовища на життєдіяльність людських угруповань, визнання цього середовища як головного чинника соціального розвитку.

Цю ідею удосконалив К. Ріттер (K. Ritter), який розглядав земну поверхню як арену людської діяльності і шукав пояснення людської історії в явищах природи, тому перше місце відводив фізичній географії.

Але на початку XX ст., як зазначає С. Березовські, виникла доктрина посибілізму про поступове зростання можливостей суспільства перетворювати природу і запобігати іiї катастрофічним змінам. При цьому наголошувалось, що роль географічного середовища не настільки значна, як це вважали раніше, і їі не варто абсолютизувати. Зі зростанням технічної озброєності суспільства воно дедалі менше залежить від особливостей природного середовища. Учений наголошує, що поява географії людини і антропогеографії поклала початок дезінтеграції географічної науки і констатує, що у період між двома світовими війнами почала розвиватися економічна географія, а дезінтеграція географічної науки досягла найвищого рівня фізична та економічна географія відокремились одна від одної [8].

Аналізуючи иі міркування, на нашу думку, твердження про не настільки значну роль географічного середовища, як ие вважсали раніше, є сумнівними у зв'язку зі значним погіршенням екостану природного середовища і природними катаклізмами значних масштабів.

Майже ідентичні з С. Березовські міркування висловлюють й інші зарубіжні географи. Наприклад, Дуглас Ян (Douglas Ian), досліджуючи взаємовплив суспільної та фізичної географії, дійшов висновку, що хоч фізико-географи і економіко-географи навчаються і працюють організаційно разом, кожна з галузей розвивається своїм шляхом. «Сфера діяльності фізичної географії так само стара, як і ії предмет. Сфера діяльності географії людини - продукт XX ст. і особливо сучасних (на кінець 80-х рр. - Б.Ч.) суспільних процесів. Якщо фізична географія вивчає суть природних явищ, то географія людини - різноманіття умов життя, людської діяльності у просторі. Головні цілі і зміст фізичної географії мало змінилися за останні 100 років, незважаючи на оволодіння нею новими методами і концепціями. Зміст географії людини за цей час суттєво змінився. Нині основними епістемологічними концепціями географії людини є позитивізм, гуманізм і структуралізм, а у фізичній географії основний науковий метод, як і раніше, - позитивістська епістемологія (підтвердження фактами гіпотези, використання концепції еволюційного розвитку, передбачення майбутніх змін середовища тощо). Це означає, що фізична географія досить стабільна». [Влияние географии человека на физическую географию (пер. с англ.). РЖ. 1988. № 7 А136. С. 21-22.].

Аналогічні висловлювання й німецького географа Бетцінга Вернера (Bätzing Werner), який у критичній статті (1992р.) відмічає: сучасний стан географічної науки характеризується таким великим розривом фізичної та суспільної географії, що між ними практично відсутня спільна мова, хоча офіційно вважається, що географія є «інтеграцією» цих двох основних напрямів. Далі автор говорить, що на фоні руйнації навколишнього середовища і значної спеціалізації в науці, економіці та суспільстві існує суспільна потреба в інтегрованих наукових концепціях, важлива роль при цьому відводиться географії як проблемно орієнтованому поєднанню ії фізичної і суспільної гілок. Автор пропонує предметом географії, як інтегрованої науки про навколишнє середовище, вважати аналіз взаємодії людини $\boldsymbol{i}$ природи $\boldsymbol{y} \ddot{\boldsymbol{u} x}$ просторовому аспекті. При цьому поєднанню фізичної та суспільної географії надається фундаментальне значення як мосту між природничими і суспільними науками. [География как интегративная наука об окружающей среде? Место географии в системе наук в постиндустриальном обществе. РЖ. 1992. № 3 A59. С. 9.].

Зауважимо, щзо ие одна з найщікавіших пропозицій, проте потрібні обтрунтовані докази та виявлені спільні закономірності єдиної географії.

Питання про єдність географії було предметом дискусій і на ХХШ Міжнародному географічному конгресі у Москві (1976р.). На конгресі у заключному виступі президента Міжнародного Географічного Союзу Ж. Дреша (Zh. Dresh; Франція), як підведення підсумків дискусій, що відбулися, і майбутніх, неоднозначно проголошено: «Безсумнівно, єдність географії не можна розуміти нині в ії минулому смислі... Країнознавча робота 3 характеристикою геології, клімату, рослинності, а також демографії, історії, економіки тощо призводить до «перераховувального» опису, до зібрання банальних матеріалів. Що 
подібна географія усе ще побутує, особливо у середніх і вищих навчальних закладах, про це можна тільки пошкодувати, оскільки вона дає неправдиве уявлення про нашу науку і заважає географам включитися в активне повсякденне життя... Необхідно утверджувати принцип єдності географії, оскільки метою іiі є вивчення просторових зв'язків між природним середовищем і людиною. У цій меті іiі специфіка та iї своєрідність порівняно з іншими науками. Зусилля вчених майже усіх країн світу у цьому напрямку помітні..., проте вони поки що дещо безладні» [3, с. 8].

Слід зазначити, що «перераховувальний» опис, на жаль, залишився й донині як у вищій школі, так $і$ у середній. Напевно, перебудовуватися набагато важче, ніж мріяти про иее.

\section{Висновки}

Світова тенденція у другій половині XX ст. призвела до стрімкої диференціації в науці, зокрема й географії, поставивши перед наукою безліч великих і малих проблем, зокрема збереження єдності географічної науки, iї переосмислення в умовах лавиноподібного накопичення знань, їх швидкого старіння й оновлення із застосуванням математичних методів дослідження і комп'ютерної обробки отриманих даних. Разом з тим, застосування математичних методів і системного підходу дослідження потребували зміни у географів самого стилю наукового мислення, яке відбувалося не завжди безболісно.

Усе це у 60-ті роки XX ст. призвело до кризи в географічній науці. По-перше, більшість географів була не готова швидко перебудуватись у нових умовах; по-друге, не було своєчасно налагоджено підготовку географів нової генерації.

Звичайно, географічна наука знаходиться в постійній певній кризовій ситуації, оскільки не завжди встигає за надзвичайно прискореним темпом суспільного розвитку. Тому в ній відбуваються два закономірні процеси: диференціація та інтеграція, причому об'єднання відбувається не двома галузями фізичної й економічної географії, - а через їх дочірні дисципліни. На фоні загального позитивного поступу географічної науки, коли вдосконалюються й уточнюються наукові здобутки, розробляються програми втілення у практику теоретичних знань, $\epsilon$ ще незрозумілі потуги окремих дослідників до пошуку «нових» незвичних і не завжди обгрунтованих термінів і понять географічної науки. Але потрібно зрозуміти, що й нині зберігається (i, мабуть, ще довго буде зберігатися) принципово важлива різниця, яка існує всередині нашої науки між її фізико-географічними і економіко-географічними галузями.

\section{References [Jimepamypa]}

1. Anuchin V.A. (1972). Theoretical Foundations of Geography. Moscow: Mysl. [In Russian].

[Анучин В. А. Теоретические основы географии. - М.: Мысль, 1972. - 430 с.].

2. Battimer A. (1990). Way in Geography. Translated from the English by A.V. Tarusov. Moscow: Progress. [In Russian].

[Баттимер А. Путь в географию; пер. $з$ англ.А. В. Тарусова. - М.: Прогресс, 1990. - 440 с.]

3. Dresh Zh. (1977). Modern Geography and the International Geographical Union. Results of the XXIII International Geographical Congress. Moscow: Znaniie, 5-13. [In Russian].

[Дреш Ж. Современная география и международный географический союз / Итоги ХХШ Междунар. геогр. Конгресса. М.: Знание, 1977. - С. 5-13.]

4. Isachenko A.G. (1986). In Search of Methodological Foundations of Geography Unity. Overview Perspective. Proceedings of the $V G O, 118$ (4), 377-386. [In Russian].

[Исаченко А. Г. В поисках методологических основ единства географии (обзор точек зрения) // Известия ВГО. $-1986 .-118$. - № 4. - C. 377-386.]

5. Isachenko A.G. (1986). History of Geographical Ideas in the Researches of British and American Geographers (new books of publishing house Progress). Proceedings of the VGO, 6, 536-540. [In Russian].

[Исаченко А. Г. История географических идей в освещении британских и американских географов (новые книги издательства «Прогресс») / Известия ВГО. - 1986. - Вып. 6. - С. 536-540.]

6. Sychova L.S. (1987). The Specificity of Geography as a Science. Study of Methodological Problems of Geography in the Estonian SSR. Theses of reports and messages. Tallinn, 3-5 Feb., 1987. Tallin, 95-99. [In Russian].

[Сычова Л.С. Специфика географии как науки / Исследование методологических проблем географии в ЭССР; тезисы докладов и сообщений. Таллин, 3-5 февр., 1987. - Таллин, 1987. - С.95-99].

7. Chernov B.A., Sharukha I.M. The Peculiarities of Geographical Sciences Development in 1950-1980. Mogilev Meridian. Mogilev. Vol. 15, 1-3 (28-30), 25-29. [In Belarussian].

[Чернов Б. А., Шаруха I. М. Асаблівосці развіцця географічнай навукі у 1950-1980 гады / Магілёускі мерыдыян. - Магілёу: - Том 15. - Вип. 1-3 (28-30). - С. 25-29].

8. Berezowski S. (1985). Zintegrowany dualizm geografii. Czsopismo geograficzne. 56, 2. 129-138.

9. Julie Tuason. A. (1987) Reconciling the unity and diversity of geography. Journal of Geography (USA), 87, 5, $190-193$. 